Corps

of Engineers

Waterways Experiment

Station

\title{
Airblast Calculations for an Underground Explosion
}

\author{
by C. Wayne Mastin \\ Mississippi State University
}

Approved For Public Release; Distribution Is Unlimited

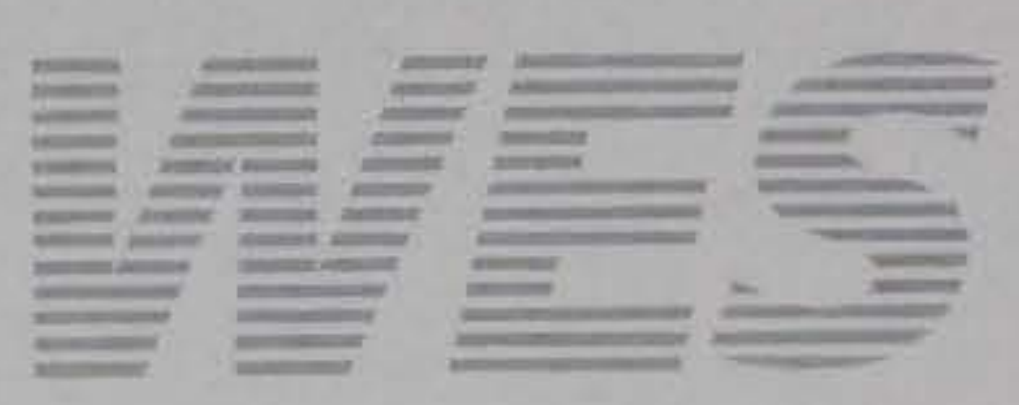

RESEARCH LIBRARY

US ARMY ENGINEER WATERWAYS

EXPERIMENT STATION

VICKSBURG, MISSISSIPPI 


\section{Airblast Calculations for an Underground Explosion}

by C. Wayne Mastin

Mississippi State University

Department of Mathematics and Statistics

Mississippi State, MS 39762

Final report

Approved for public release; distribution is unlimited

Prepared for Defense Nuclear Agency 6801 Telegraph Road

Alexandria, VA 22310-3398

Under Contract No. DACA39-91-M-4034

Monitored by Structures Laboratory

U.S. Army Engineer Waterways Experiment Station 3909 Halls Ferry Road, Vicksburg, MS 39180-6199 


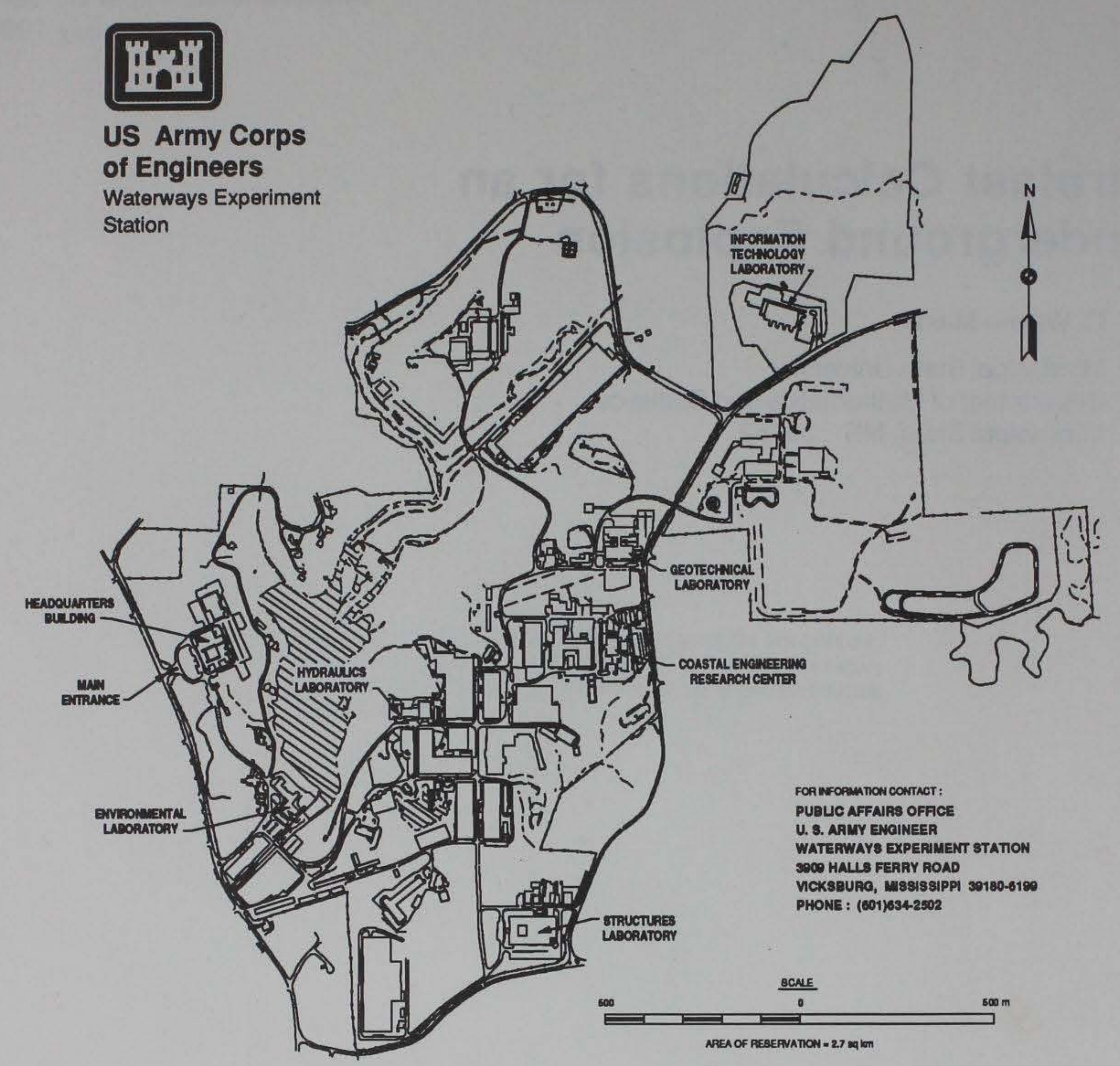

Waterways Experiment Station Cataloging-In-Publication Data

Mastin, C. Wayne.

Airblast calculations for an underground explosion / by C. Wayne

Mastin ; prepared for Defense Nuclear Agency ; monitored by

Structures Laboratory, U.S. Army Engineer Waterways Experiment

Station.

23 p. : ill. ; $28 \mathrm{~cm}$. - (Miscellaneous paper ; SL-93-5)

Includes bibliographical references.

1. Blast effect - Measurement. 2. Underground nuclear explosions -

Testing. 3. Nuclear explosions - Simulation methods. I. United

States. Defense Nuclear Agency. II. U.S. Army Engineer Waterways Experiment Station. III. Title. IV. Series: Miscellaneous paper (U.S. Army Engineer Watenways Experiment Station) ; SL-93-5.

TA7 W34m no.SL-93-5 


\section{PREFACE}

This study was conducted for Headquarters, U. S. Army Corps of Engineers, under Contract No. DACA39-91-M-4034. The work was performed under the sponsorship of the Field Command, Defense Nuclear Agency (MIPR HD 1102-1-H24A03). The research was accomplished by Dr. C. Wayne Mastin, Mississippi State University, at the Explosion Effects Division (EED), Structures Laboratory (SL), U. S. Army Engineer Waterways Experiment Station (WES), under the technical supervision of Mr. Howard G. White, EED.

This report was prepared under the general supervision of Mr. Bryant Mather, Director, SL, and Mr. L. K. Davis, Chief, EED.

At the time of publication of this report, Director of WES was Dr. Robert W. Whalin. Commander was COL Leonard G. Hassell, EN. 


\section{Contents}

1 PREFACE 1

2 LIST OF FIGURES

3 INTRODUCTION 4

4 COMPUTATIONAL PROCEDURES 4

5 COMPUTATIONAL RESULTS 5

6 CONCLUSIONS AND RECOMMENDATIONS 6

7 REFERENCES $\quad 7$

8 FIGURES 18 


\section{LIST OF FIGURES}

1. Gage locations and computational regions for the Midnight Hour II simulation.

2. Solution for the Midnight Hour II simulation at time $=1 \mathrm{msec}$.

3. Solution for the Midnight Hour II simulation at time $=2 \mathrm{msec}$.

4. Solution for the Midnight Hour II simulation at time $=5 \mathrm{msec}$.

5. Solution for the Midnight Hour II simulation at time $=9 \mathrm{msec}$.

6. Solution for the Midnight Hour II simulation at time $=20 \mathrm{msec}$.

7. Solution for the Midnight Hour II simulation at time $=30 \mathrm{msec}$.

8. Pressure time history comparison of the calculated and the experimental data $(\mathrm{AB} 1, \mathrm{AB} 6)$ at the $3.2 \mathrm{~m}$ range. Times-of-arrival have been adjusted for comparison.

9. Pressure time history comparison of the calculated and the experimental data $(\mathrm{AB} 2, \mathrm{AB} 7)$ at the $3.8 \mathrm{~m}$ range. Times-of-arrival have been adjusted for comparison.

10. Pressure time history comparison of the calculated and the experimental data (AB3, AB8) at the $6.0 \mathrm{~m}$ range. Times-of-arrival have been adjusted for comparison.

11. Pressure time history comparison of the calculated and the experimental data (AB4, AB9) at the $7.5 \mathrm{~m}$ range. Times-of-arrival have been adjusted for comparison.

12. Pressure time history comparison of the calculated and the experimental data $(\mathrm{AB} 5, \mathrm{AB} 10)$ at the $8.0 \mathrm{~m}$ range. Times-of-arrival have been adjusted for comparison. 


\section{AIRBLAST CALCULATIONS FOR AN UNDERGROUND EXPLOSION}

\section{INTRODUCTION}

The Midnight Hour II (MH II) event was the explosion of a 1000-pound spherical charge of nitromethane, buried $2.5 \mathrm{~m}$ below the soil surface. Airblast gages were used to measure side-on overpressures at several locations on the surface. The data reveals a precursed wave front followed by pressure fluctuations that persisted for a duration of up to $100 \mathrm{msec}$. The HULL hydrodynamics code was used to numerically model the MH II event. It became clear before the computations were started that solving a problem over such a long time interval with the length scales involved would require a lot of computer power. Therefore all computations have been done on the Cray YMP at the U. S. Army Engineer Waterways Experiment Station (WES). Even on the Cray, the computation of a complete simulation on a single grid would have required weeks of CPU time. In order to reduce this to days, we used the "firein" option in the HULL code, which allows a solution to be restarted on a new grid. Thus, we were able to start the solution with a fine grid about the explosive charge and then extend the grid out past the gage locations as the solution developed.

\section{COMPUTATIONAL PROCEDURES}

The problem geometry was assumed to be axisymmetric, with a vertical axis of symmetry passing through the center of the explosion. The materials used in the MH II simulation were chosen from the HULL material library (see [1]) to match the experiment as close as possible. The explosive charge was a spherical container filled with nitromethane, with a radius of $43.88 \mathrm{~cm}$, and a net explosive weight of about 1000 pounds $(454 \mathrm{~kg})$. The soil was modeled as dry Eglin AFB sand. The Doan-Nickel equation of state was used in the air model. That equation of state provides a better fit to the actual behavior of air in explosion problems than does the gamma law for air. A change in the lower limit of the pressure of the soil was made in the material library. This lower limit was set to one atmosphere. This was necessary to stabilize the computations, as explained below, rather that to match the experimental properties. Because the pressure waves in the soil were much stronger than those in the atmosphere, it was also necessary to raise the stations representing the gage locations. The stations were placed $10 \mathrm{~cm}$ above the soil surface rather than on the surface itself. This distance was found to be sufficient to avoid instabilities along the soil/air interface.

The MH II simulation has been computed up to a time of $70 \mathrm{msec}$ after detonation, using a three-stage computation. The MH II event and the three regions which were 
gridded for these computations are depicted in Figure 1. The ten gages, AB1 through $\mathrm{AB} 10$, are indicated at their respective distances from ground zero. The first stage of the solution started on a 200 by 400 grid centered about the nitromethane charge, with a grid size of $1 \mathrm{~cm}$ by $1 \mathrm{~cm}$. This grid was used to compute the solution up to a time of $1 \mathrm{msec}$. The solution was then transferred to a 300 by 300 grid with $2 \mathrm{~cm}$ by $2 \mathrm{~cm}$ cells. The second grid was chosen to correctly model the blast front as it broke through the soil surface, and to simulate the formation of the resulting shock wave in the air. The lower boundary of the grid was a horizontal line through the center of the charge. Along the lower boundary, reflective boundary conditions were used since it was felt that the solution had progressed far enough so that minor errors in the boundary conditions would have negligible effect on the solution values at the gage locations. The grid extended down-range a distance of $600 \mathrm{~cm}$ and included the first three gage locations, AB1/AB6 (3.2 m), AB2/AB7 (3.8 m), and AB3/AB8 (6.0 m). The third stage of the calculations was computed on a 400 by 200 grid ( $3 \mathrm{~cm}$ by 3 $\mathrm{cm}$ cells) that extended down-range a distance of $1200 \mathrm{~cm}$. The purpose of this grid was to track the blast front as it moved past the remaining gage locations AB4/AB9 $(7.5 \mathrm{~m})$ and $\mathrm{AB} 5 / \mathrm{AB} 10(8.0 \mathrm{~m})$.

\section{COMPUTATIONAL RESULTS}

The numerical solution computed with the HULL code has been monitored using pressure and velocity plots for various times after detonation, as well as time history plots, which can be compared with experimental values. The solution at a time of 1 msec is plotted in Figure 2. As can be seen, a well-formed, symmetrical blast front initially extends around the charge. The solution was transferred to the second grid at this time, while the front was still below the soil surface. A plot of the solution as the blast front nears the soil surface appears in Figure 3. The next three plots (Figures 4, 5, and 6) describe the formation of the wave front along the surface of the soil. The difference in wave speed in the air and soil is indicated by the discontinuity in the contour lines at the interface. Some deterioration in the quality of the solution is also evident, especially along the interface between the air and soil. This is most likely due to the discontinuity in the material properties along the interface. Even using a finer grid did not seem to help a great deal.

In order to prevent a complete deterioration of the solution, a solid wall was used along the soil surface, beginning at a distance of $300 \mathrm{~cm}$ from the axis of symmetry. This allowed the wave front to travel down the surface, but prevented the high frequency oscillations in the soil from contaminating the solution in the atmosphere. However, the precursed wave front that was evident in the experimental data did not show up in the numerical solution. The computed wave front near the last gage is plotted in Figure 7. Five stations have been included to monitor the calculation at the gage locations. Figures 8 through 12 compare the calculated pressures with the two experimental values at each range. Note that the atmospheric pressure has been 
subtracted from the computed pressure to compare with the experimental data in this last set of plots. The computed solution was stopped after $70 \mathrm{msec}$, since the computed pressures were obviously diverging from the experimental data, and further computations would have been meaningless.

The time-of-arrivals on all of these figures have been aligned for ease of comparison. As in past computations with the HULL code, the time-of-arrival was not very accurate. There are several possible explanations for this occurrence. First of all, the explosive consists of detonated nitromethane (i.e., the high-pressure concentration of post-detonation gas products), since the HULL material library does not include undetonated nitromethane. By not modeling the detonation of the explosive, we would expect a shorter time-of-arrival, which indeed is seen in the computational solution at the first two gage locations. The soil model could also affect the time-of-arrival at the gages. The soil has been modeled as dry sand, which is more porous and less dense than most soils. The computed time-of-arrival at the last three gage locations is longer than that of the experiment. This is primarily because of the lower pressure values behind the blast front.

The results so far are quite reasonable, considering the length of the time interval and the large variations in pressure magnitudes in the computational field. As discussed above, a few minor modifications were necessary in the computational model of the MH II event. In order to obtain reasonable calculated values of pressure, the gage locations were raised $10 \mathrm{~cm}$ above the soil surface. This was necessary to avoid highfrequency instabilities in the numerical solution along the material interface between the soil and air. Some evidence of this problem can be seen in Figure 5. The material library in the HULL code was modified to set the lower bound of the pressure in the sand to atmospheric pressure. This was necessary because the pressure extremes in the sand tended to propagate into the air, and the result was an extremely strong (and unrealistic) sink in the atmosphere.

This solution was computed on three different grids with different cell sizes. Therefore the time step was different for each of the grids. As a result, the computer time required to advance the solution over a set time interval differed in the three stages of the computation. On the average, it took approximately 1 hour of CPU time on the WES Cray YMP to advance the solution $1 \mathrm{msec}$. The HULL code used in these computations is Version 122.0, which has not been extensively vectorized for efficiency.

\section{CONCLUSIONS AND RECOMMENDATIONS}

The results of these computations indicate that the HULL hydrocode can be a useful predictive tool in estimating the airblast effects of shallow underground explosions on surface structures. The main difficulty that was encountered was in the region of the soil/air interface. It may have helped if more grid points had been located near the interface, but even then, some numerical problems would likely have occurred simply 
due to the discontinuities in material properties along the interface. The failure to resolve the precursed wave front was the major qualitative deficiency in the numerical solution. However, this was not unexpected. The correct modeling of the precursed front is a difficult numerical problem that requires complicated numerical schemes, such as turbulence modeling, that are not included in the HULL program.

Techniques for modeling precursed airblast waveforms may be found in the report by Needham, et al. [2]. It should be noted that the failure to model the precursed front is related to the difficulties encountered in computing the solution along the soil/air interface, and the fact that the surface pressure values referred to in the pressure plots were actually taken $10 \mathrm{~cm}$ above the soil surface.

\section{REFERENCES}

1. D. A. Matuska and J. J. Osborn, "HULL Documentation", Orlando Technology, Inc., Shalimar, Florida, 1987.

2. C. E. Needham, J. E. Crepeau, K. E. Sneider, and L. W. Kennedy, "Theoretical Calculations for Precursor Definition", Report No. DNA-TR-90-18, Defense Nuclear Agency, Alexandria, Virginia, September, 1990. 


\section{FIGURES}




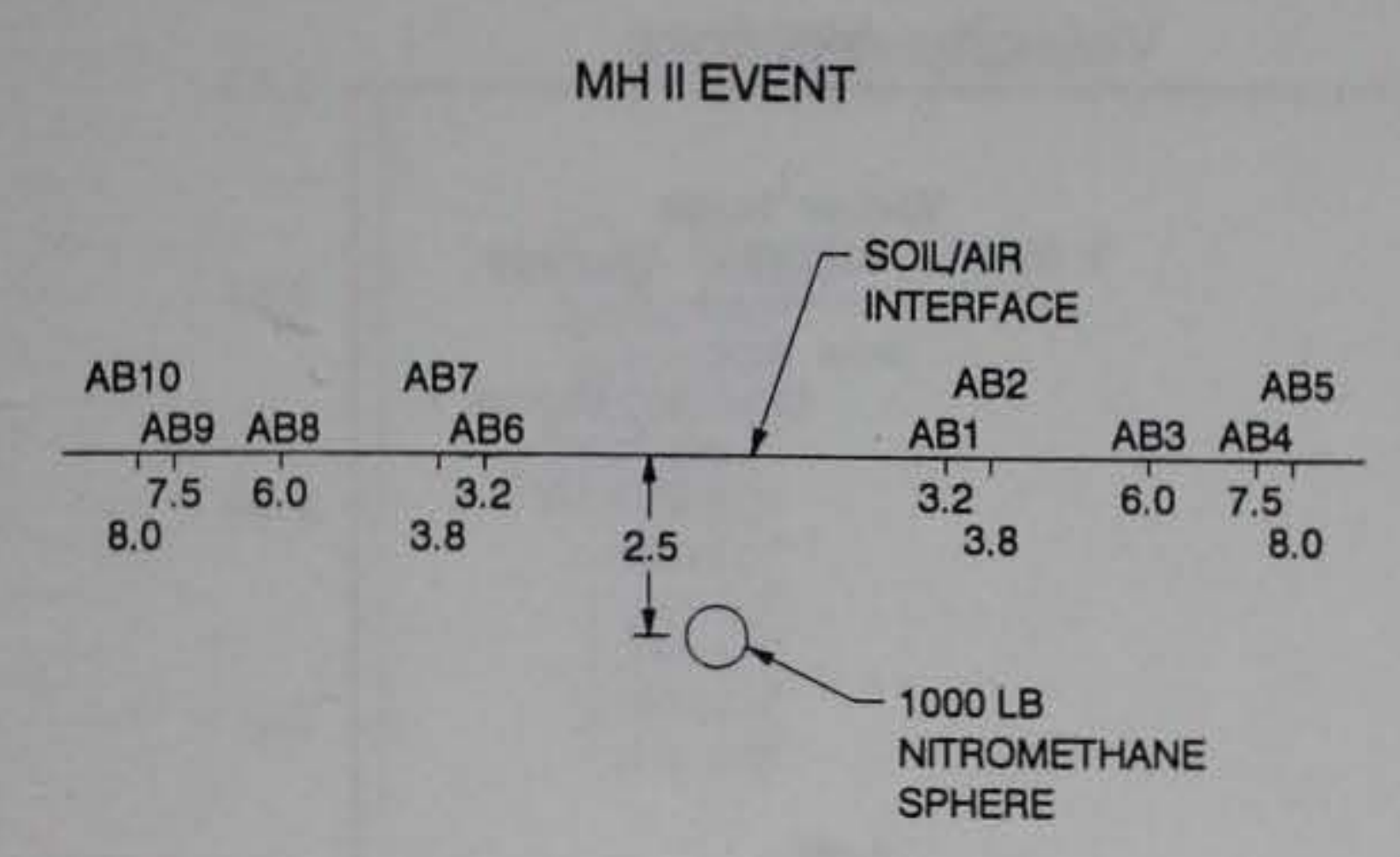

ALL RANGES IN METERS

MH I CALCULATION: STAGE ॥

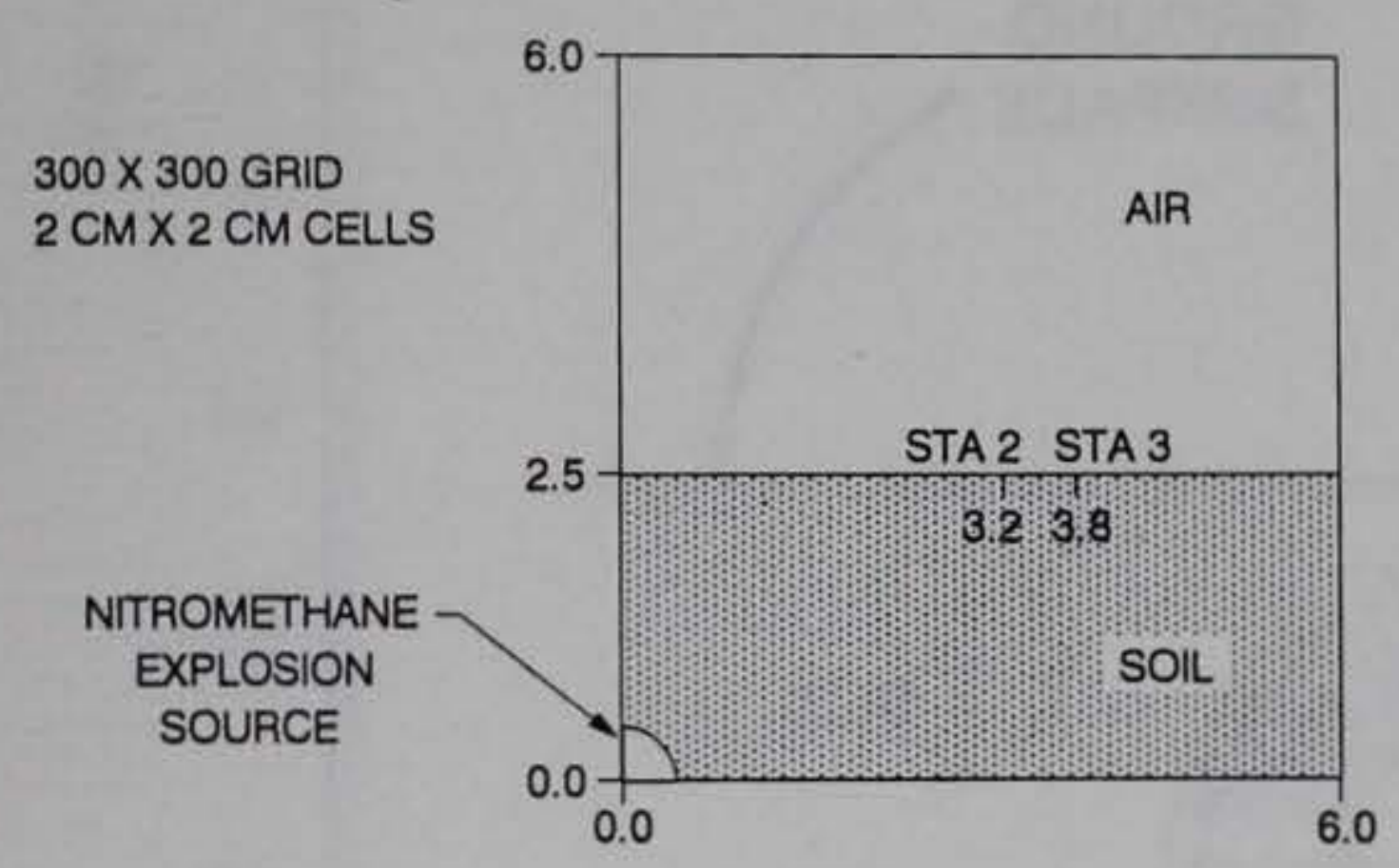

\section{MH II CALCULATION: STAGEI}

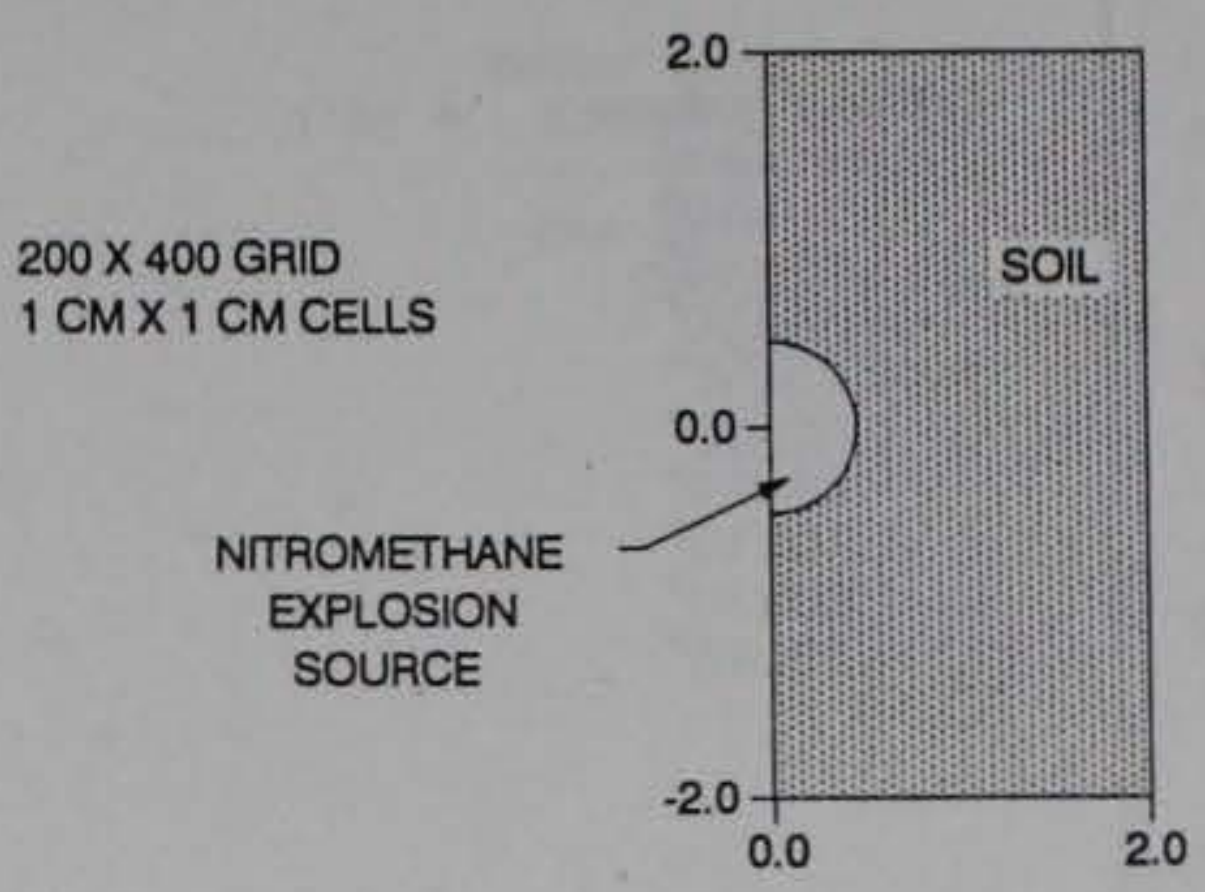

MH II CALCULATION: STAGE II

$400 \times 200$ GRID 3 CM X 3 CM CELLS

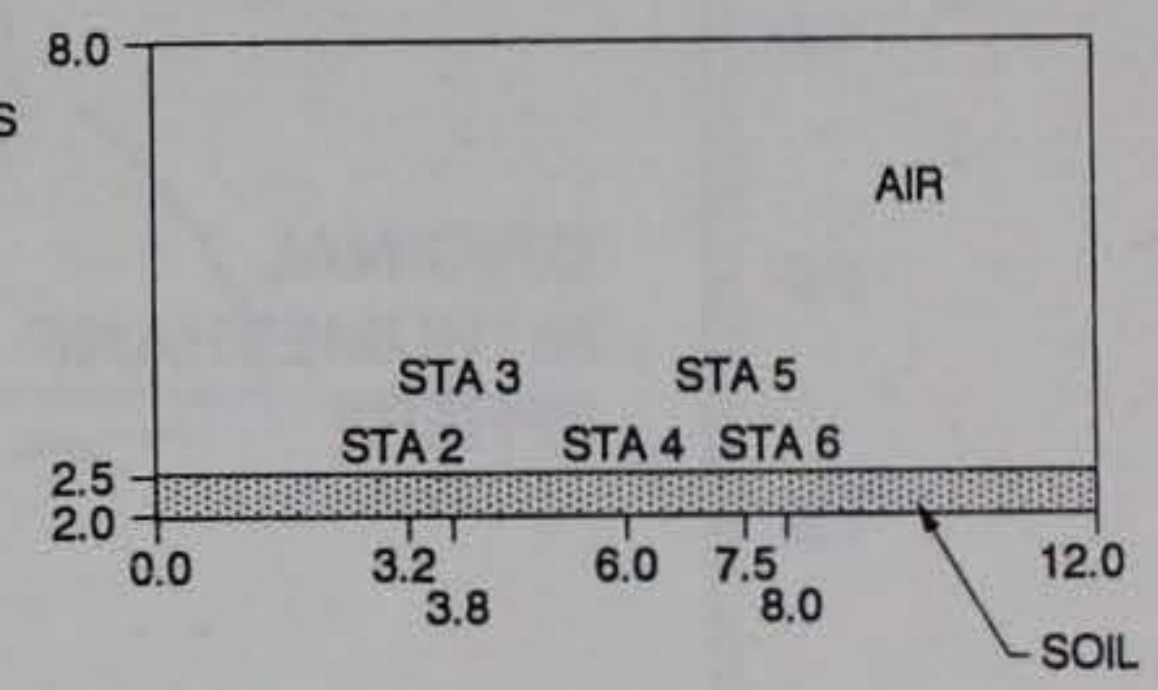

Figure 1. Gage locations and computational regions for the Midnight Hour II simulation. 


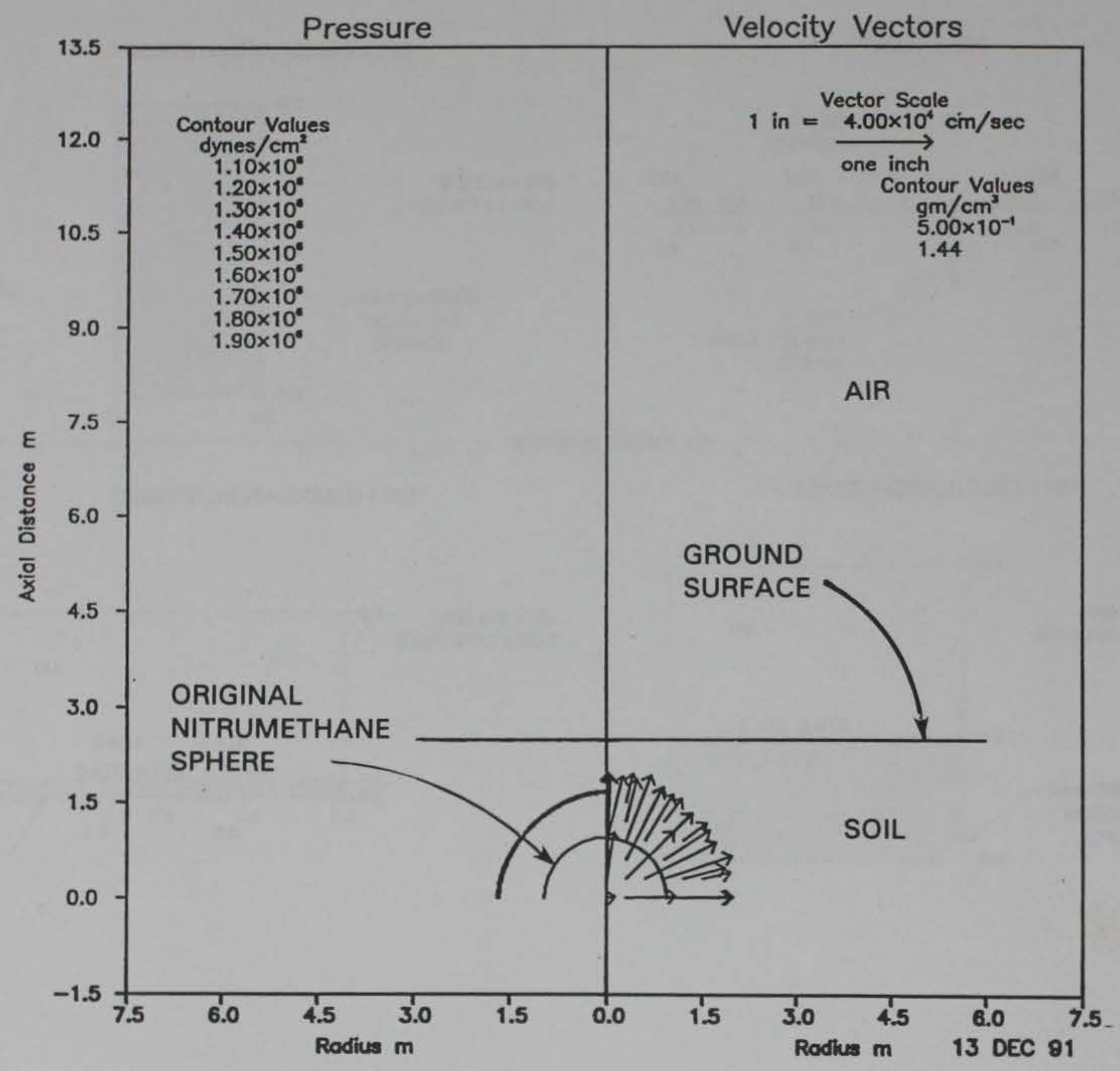

Figure 2. Solution for the Midnight Hour II simulation at time $=1 \mathrm{msec}$. 


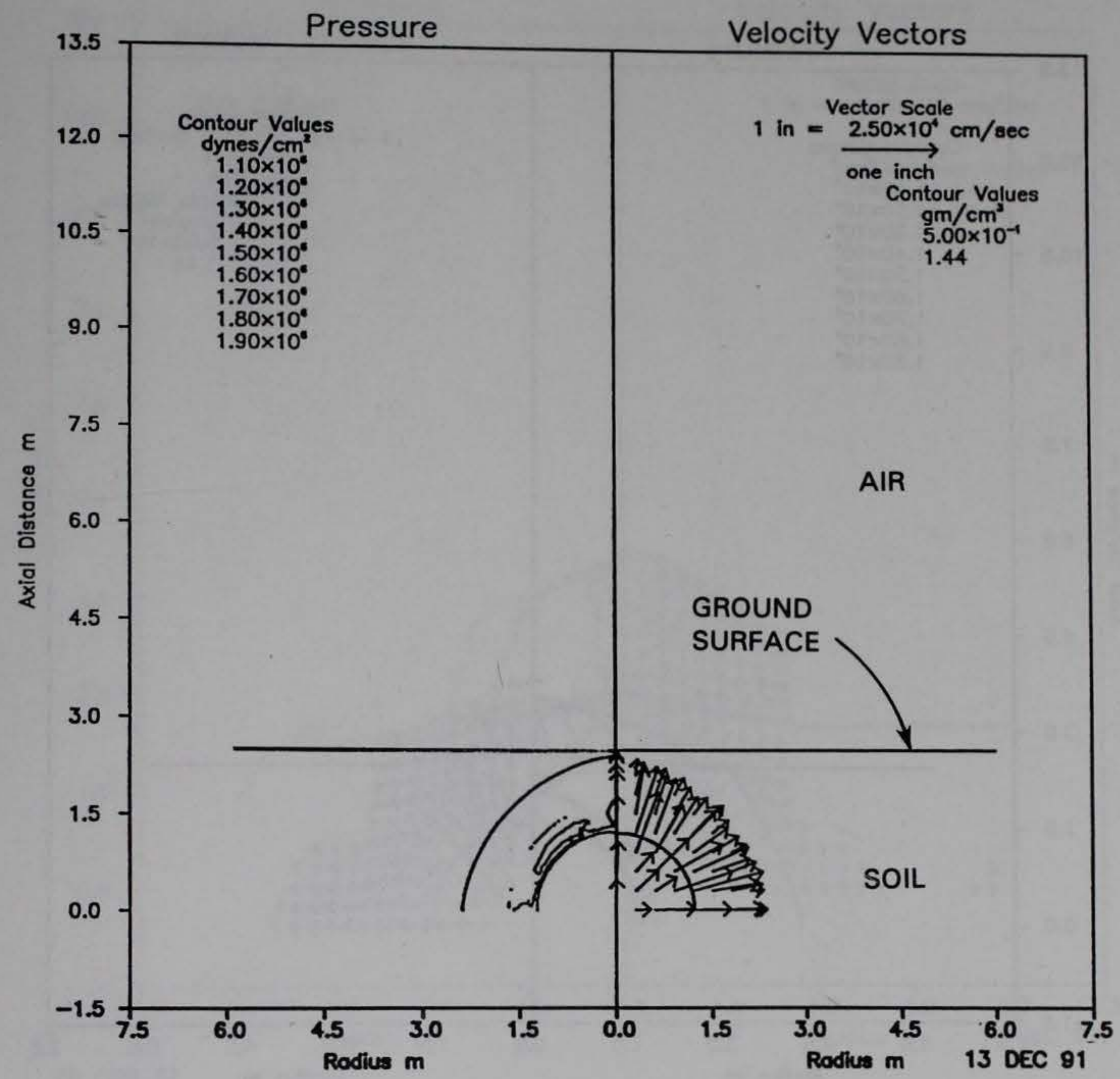

Figure 3. Solution for the Midnight Hour II simulation at time $=2 \mathrm{msec}$. 


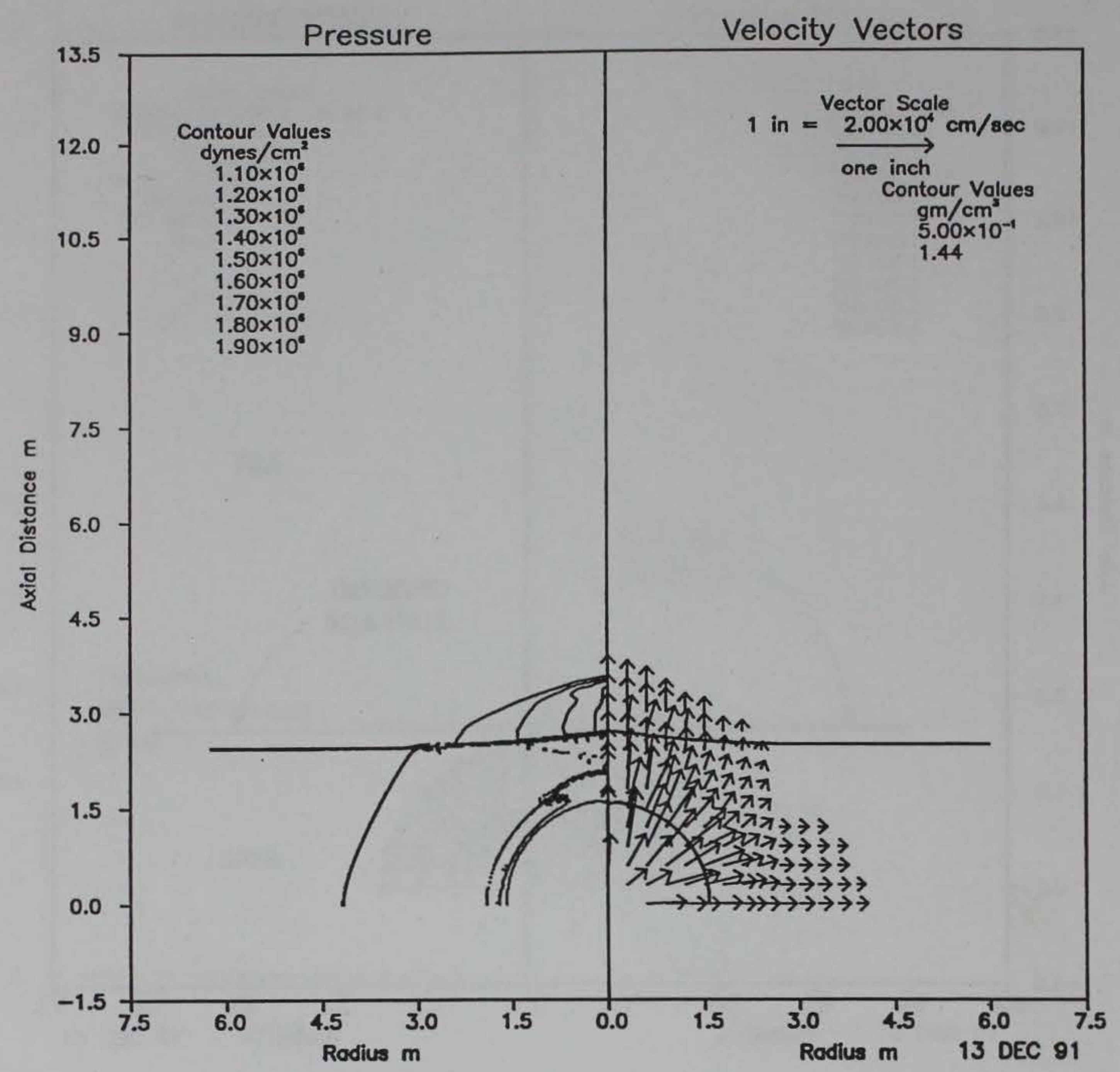

Figure 4. Solution for the Midnight Hour II simulation at time $=5 \mathrm{msec}$. 


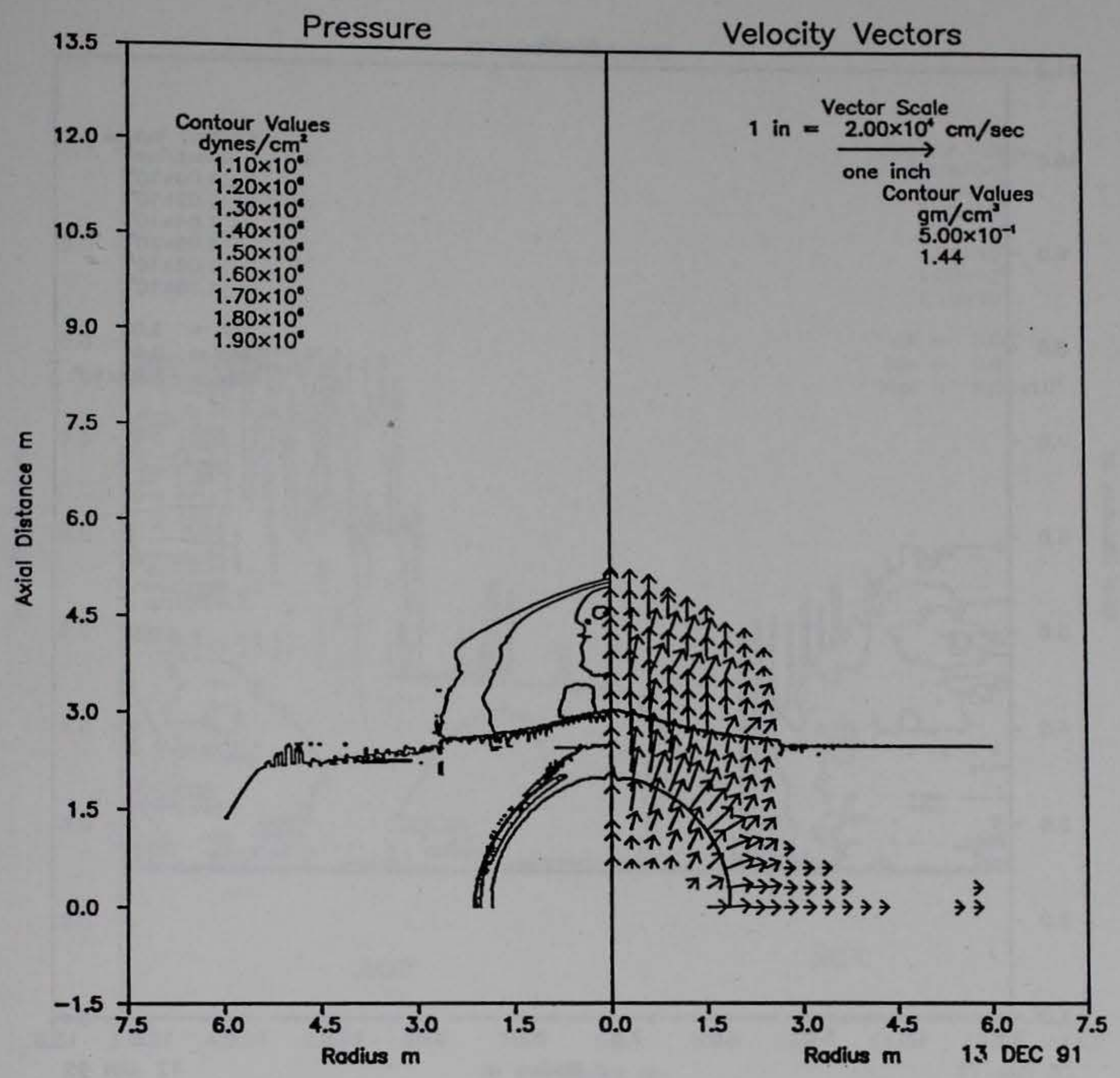

Figure 5. Solution for the Midnight Hour II simulation at time $=9 \mathrm{msec}$. 


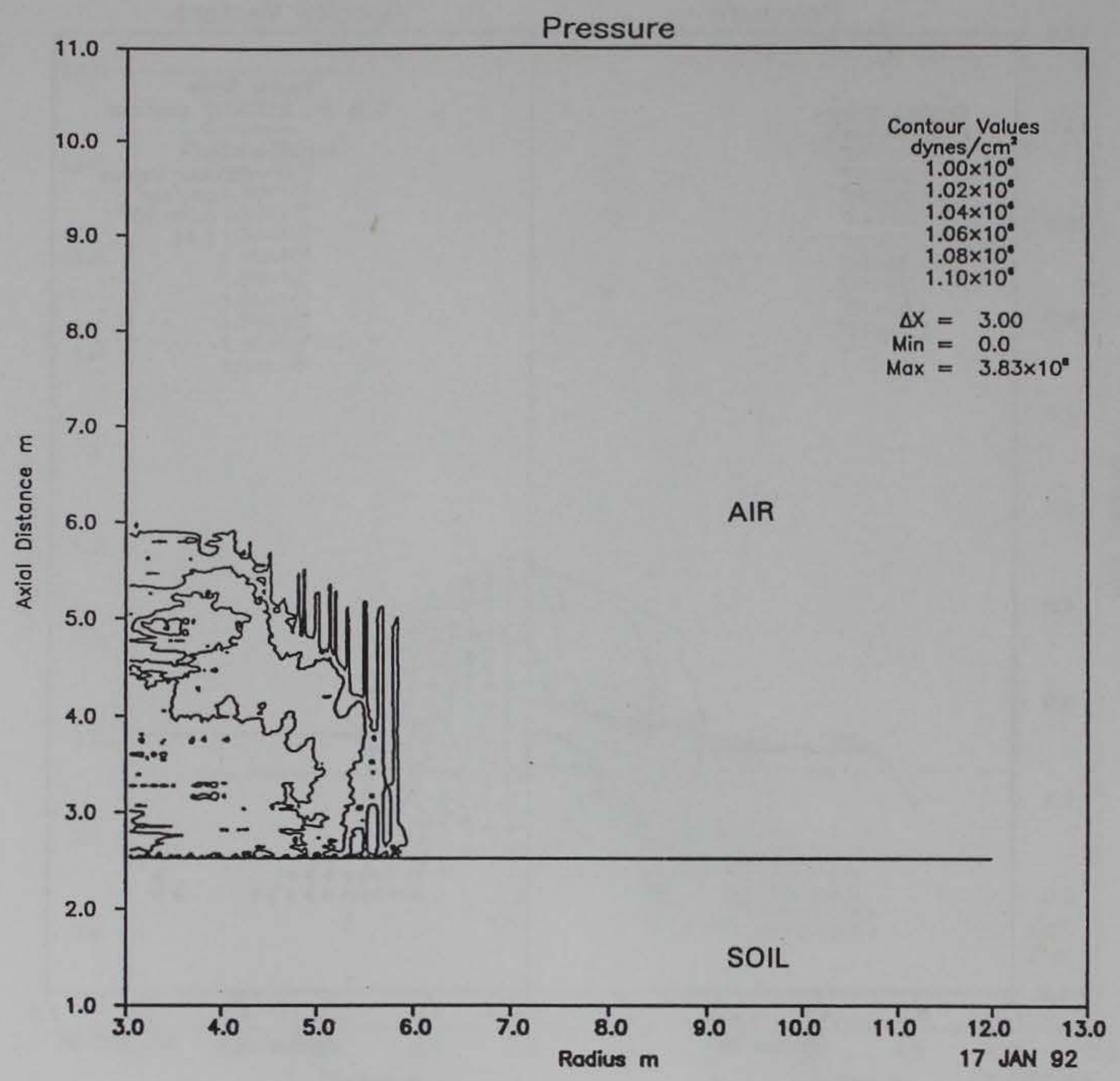

Figure 6. Solution for the Midnight Hour II simulation at time $=20 \mathrm{msec}$. 


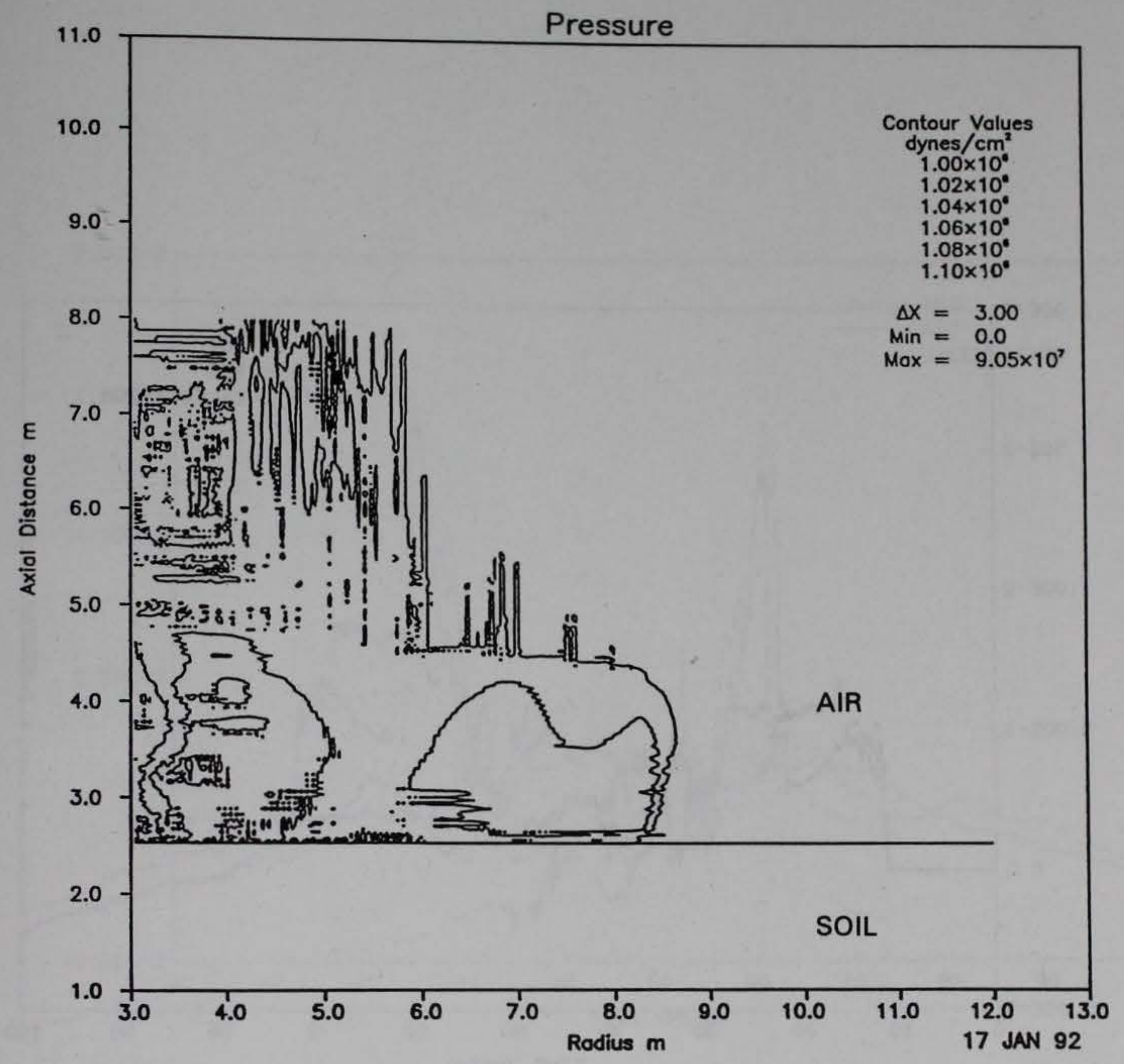

Figure 7. Solution for the Midnight Hour II simulation at time $=30 \mathrm{msec}$. 


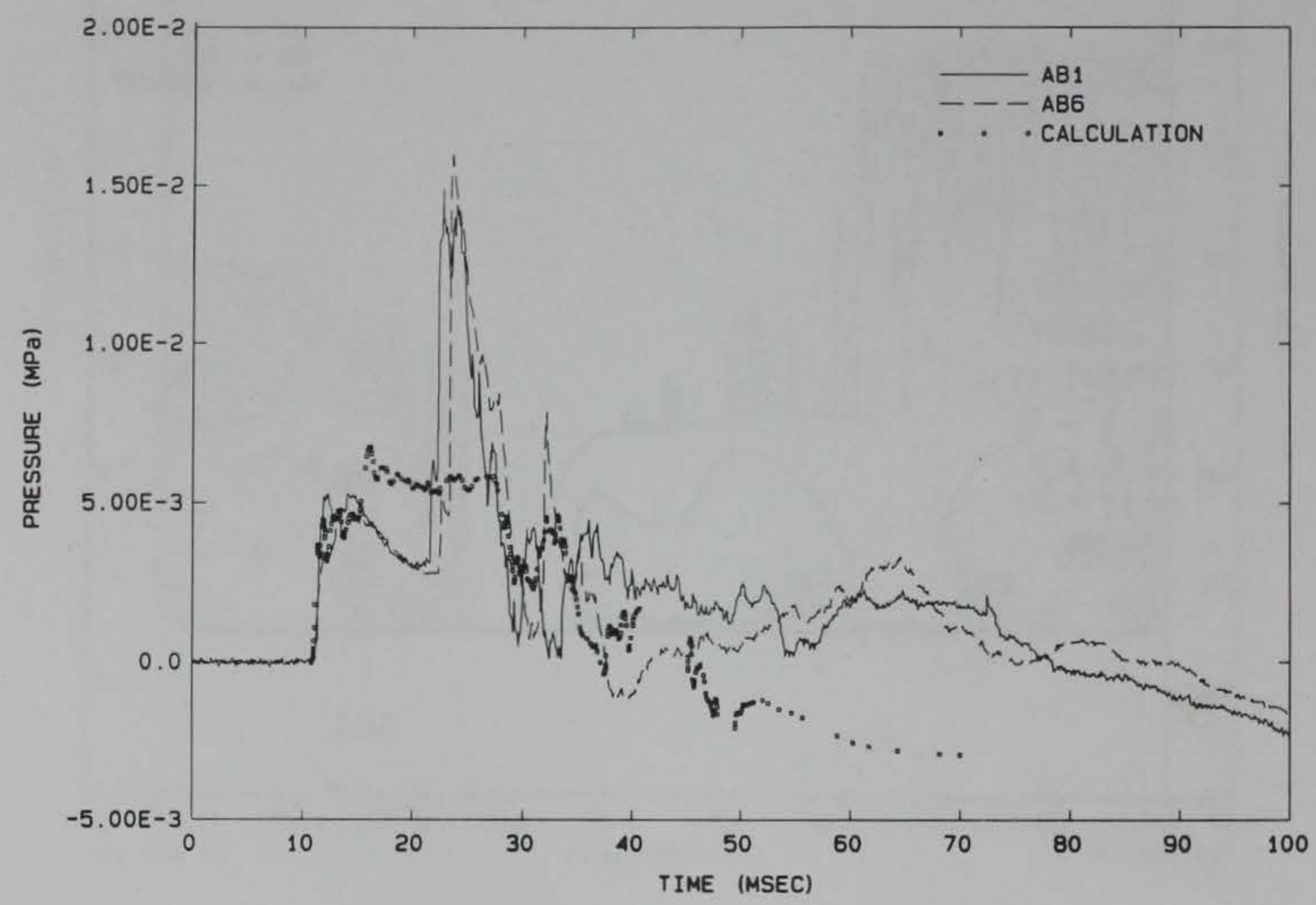

Figure 8. Pressure time history comparison of the calculated and the experimental data $(\mathrm{AB} 1, \mathrm{AB} 6)$ at the $3.2 \mathrm{~m}$ range.

Times-of-arrival have been adjusted for comparison. 




Figure 9. Pressure time history comparison of the calculated and the experimental data $(\mathrm{AB} 2, \mathrm{AB} 7)$ at the $3.8 \mathrm{~m}$ range.

Times-of-arrival have been adjusted for comparison. 


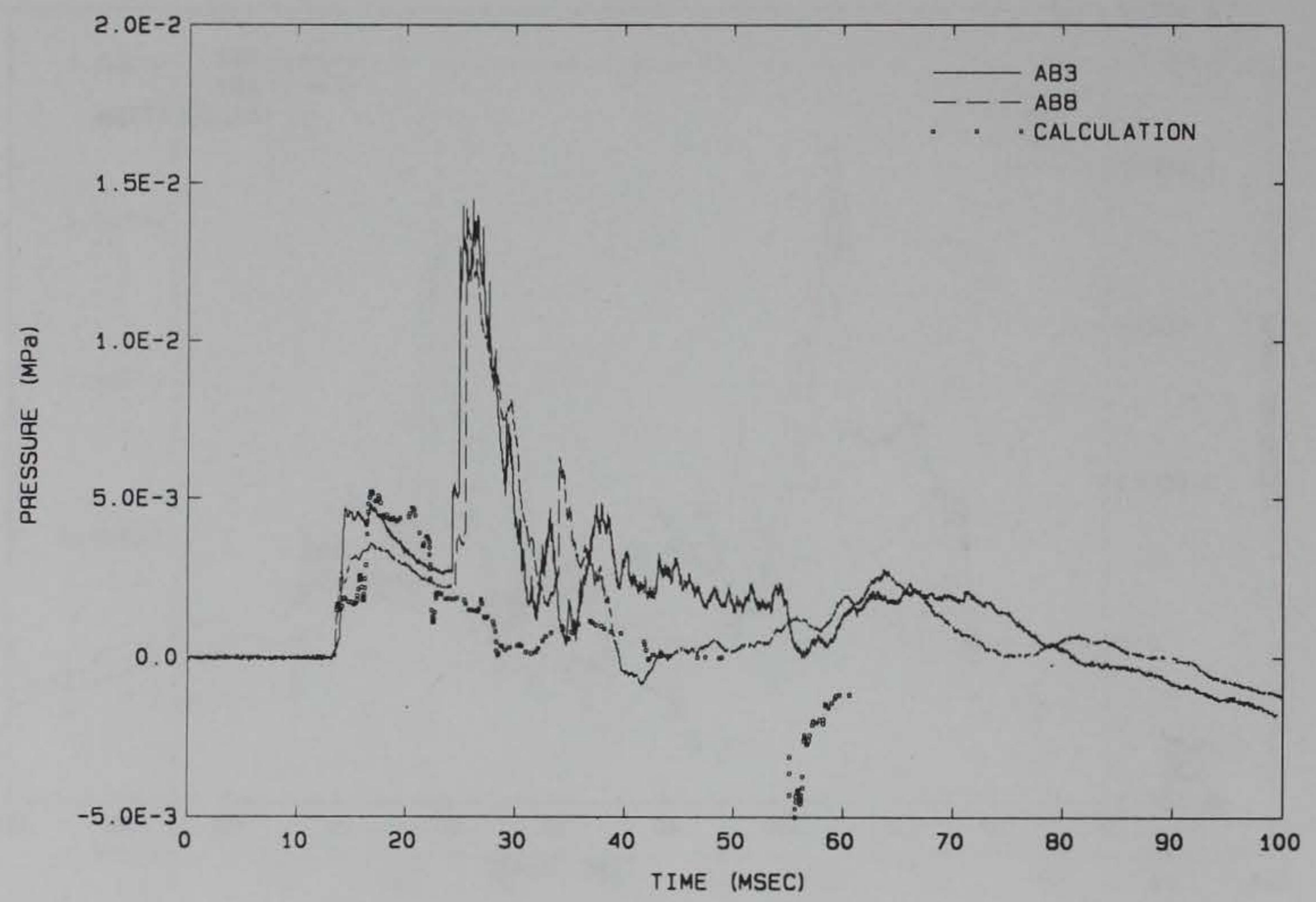

Figure 10. Pressure time history comparison of the calculated and the experimental data $(\mathrm{AB} 3, \mathrm{AB} 8)$ at the $6.0 \mathrm{~m}$ range. Times-of-arrival have been adjusted for comparison. 


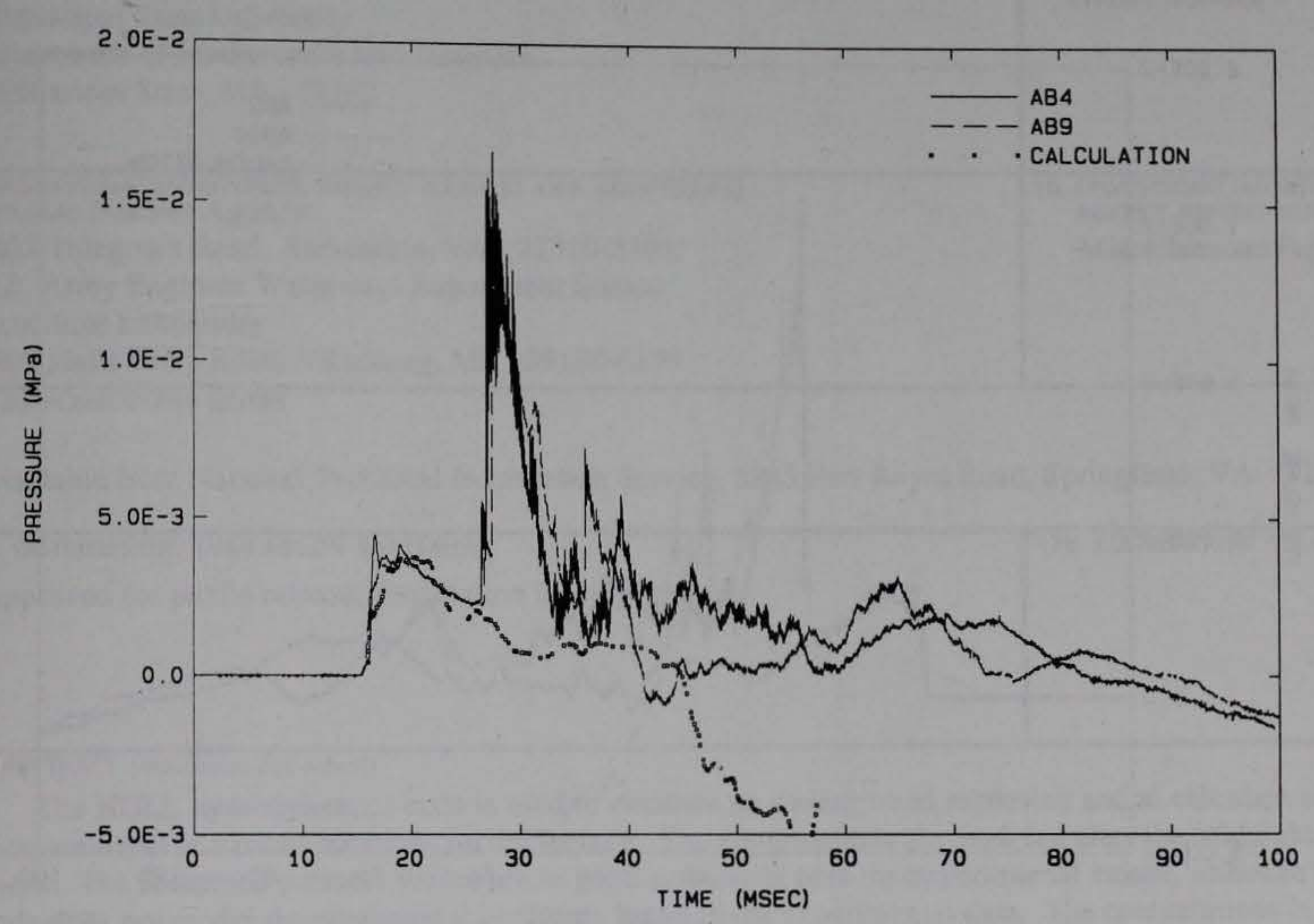

Figure 11. Pressure time history comparison of the calculated and the experimental data (AB4, AB9) at the $7.5 \mathrm{~m}$ range.

Times-of-arrival have been adjusted for comparison. 


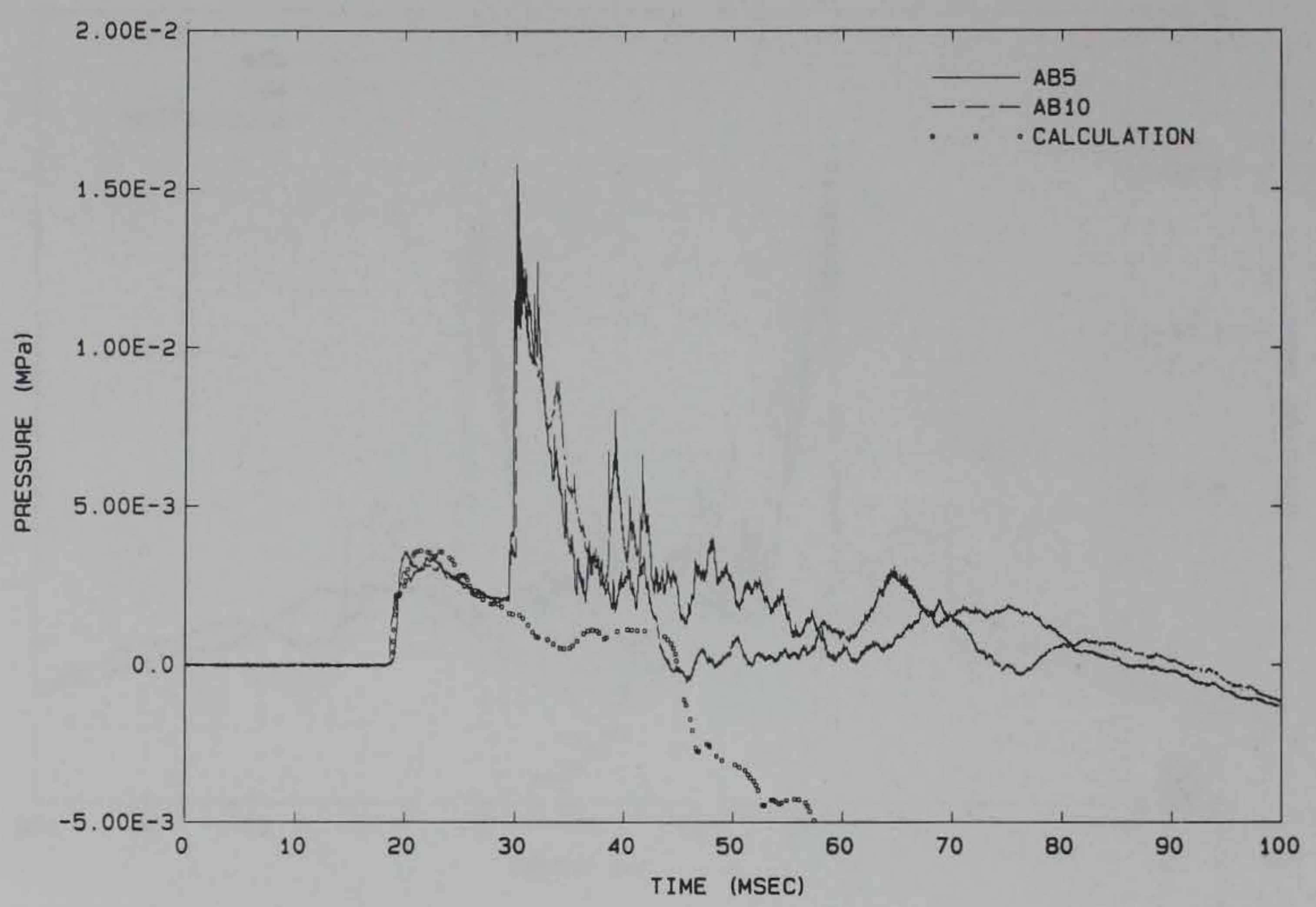

Figure 12. Pressure time history comparison of the calculated and the experimental data $(\mathrm{AB} 5, \mathrm{AB} 10)$ at the $8.0 \mathrm{~m}$ range. Times-of-arrival have been adjusted for comparison. 


\section{REPORT DOCUMENTATION PAGE}

Public reporting burden for this collection of information is estimated to average 1 hour per response, including the time for reviewing instructions, searching existing data sources. coliection of information, including suggestions for reducing this burden. to Washington of information. Send comments regarding this burden estimate or any other aspect of this Davis Highway, Suite 1204, Arlington, VA 22202-4302, and to the Office of Management and Budget, Papenvori Peduction Proj information Operations and Reports, 1215 jefferson

1. AGENCY USE ONLY (Leave blank) T2. REPORT DATE

3. REPORT TYPE AND DATES COVERED

4. TITLE AND SUBTITLE

July 1993

Final report

Airblast Calculations for an Underground Explosion

6. AUTHOR(S)

C. Wayne Mastin

7. PERFORMING ORGANIZATION NAME(S) AND ADDRESS(ES)

Mississippi State University

Department of Mathematics and Statistics

Mississippi State, MS 39762

9. SPONSORING/MONITORING AGENCY NAME(S) AND ADDRESS(ES)

Defense Nuclear Agency

6801 Telegraph Road, Alexandria, VA 22310-3398;

U.S. Army Engineer Waterways Experiment Station

Structures Laboratory

3909 Halls Ferry Road, Vicksburg, MS 39180-6199

11. SUPPLEMENTARY NOTES

Available from National Technical Information Service, 5285 Port Royal Road, Springfield, VA 22161.

12a. DISTRIBUTION/AVAILABILITY STATEMENT

Approved for public release; distribution is unlimited

12b. DISTRIBUTION CODE

\section{ABSTRACT (Maximum 200 words)}

The HULL hydrodynamics code is used to simulate an underground explosion and to calculate airblast measurements at various locations on the surface. The computations are modeled after the Midnight Hour II event. The computed pressure values are in good agreement with the experimental values, although the HULL code does not model the precursed wave forms found in the experimental data. The computations in this report demonstrate the capability of simulating a blast front which travels through a region composed of multiple materials with differing wave speeds. In order to conserve computer time, the HULL "firein" option was used which allows the continuation of an existing solution on a new grid. Three different grids were used to simulate the Midnight Hour II event from initial explosion up to a time of $70 \mathrm{msec}$.

\begin{tabular}{|l|l|}
\hline $\begin{array}{l}\text { 14. SUBJECT TERMS } \\
\text { Airblast } \\
\text { Grid }\end{array}$ & $\begin{array}{l}\text { Hydrocode } \\
\text { Underground explosion }\end{array}$ \\
\hline $\begin{array}{l}\text { 17. SECURITY CLASSIFICATION } \\
\text { OF REPORT } \\
\text { UNCLASSIFIED }\end{array}$ & $\begin{array}{l}\text { 18. SECURITY CLASSIFICATION } \\
\text { OF THIS PAGE } \\
\text { UNCLASSIFIED }\end{array}$ \\
\hline
\end{tabular}

\begin{tabular}{|l|l|}
\hline & $\begin{array}{l}\text { 15. NUMBER OF PAGES } \\
23\end{array}$ \\
\cline { 2 - 2 } & 16. PRICE CODE \\
\hline $\begin{array}{l}\text { 19. SECURITY CLASSIFICATION } \\
\text { OF ABSTRACT }\end{array}$ & 20. LIMITATION OF ABSTRACT \\
\hline
\end{tabular}

